Вернигора С. М.,

канд. наук із соч. комунік., дочент,

Інститут журналістики

Київського університету імені Бориса Грінченка
Vernyhora Svitlana,

Candidate of Sciences on Social Communications, Associate Professor, Institute of Journalism of Borys Grinchenko Kyiv University

ВИКЛАДАННЯ ФАХОВИХ ДИСЦИПЛІН АНГЛІЙСЬКОЮ МОВОЮ В УКРАЇНСЬКОМУ ВНЗ: ОСВІТНІЙ ЕКСПЕРИМЕНТ ЧИ ВИМОГА СЬОГОДЕННЯ

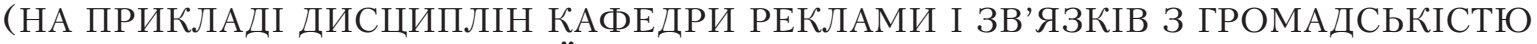
ГУМАНІТАРНОГО ІНСТИТУТУ КИЇВСЬКОГО УНІВЕРСИТЕТУ IМЕНІ БОРИСА ГРІНЧЕНКА)

\title{
TEACHING THE VOCATIONAL SUBJECTS IN ENGLISH AT THE UKRAINIAN HIGHER EDUCATION INSTITUTIONS: EDUCATIONAL EXPERIMENT OR TODAY'S CHALLENGE \\ (THE CASE OF DISCIPLINES OF THE DEPARTMENT OF ADVERTISING AND PUBLIC RELATIONS OF HUMANITARIAN INSTITUTE OF BORYS GRINCHENKO KYIV UNIVERSITY)
}

\begin{abstract}
Анотачія. Публікачія присвячена досвіду викладання англійською мовою профільних дисциплін «Копірайтинг

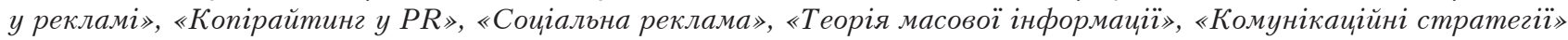
кафедри реклами $i$ зв'язків з громадськістю Гуманітарного інституту Київського університету імені Бориса Грінченка. Представлені мета, результати та перспективи розвитку такого напряму навчання студентів. Ключові слова: вища освіта, реклама і зв'язки з громадськістю, викладання дисциплін англійською мовою.
\end{abstract}

\begin{abstract}
The article is devoted to the experience of teaching in English of the profile disciplines "Copywriting in advertising", "Copywriting in PR", "Public service advertising", "Theory of mass information", "Communication strategies" of the Department of Advertising and Public Relations of Humanitarian Institute of Borys Grinchenko Kyiv University. The purpose, results and prospects of development of such direction of students' teaching are represented. Keywords: higher education, advertising and public relations, teaching the disciplines in English.
\end{abstract}

$\mathrm{B}$ ступ. Питання нагальності використання англійської мови в освітній галузі обговорюються вже тривалий час. Найпоширенішою є вимога до науково-педагогічних працівників вищих навчальних закладів щодо володіння англійською мовою (щонайменше на рівні В2) та створення при університетах мовних курсів 3 метою підвищення кваліфікації викладачів ВНЗ. Проте питання вибору методики викладання фахових дисциплін англійською мовою залишається одним із найбільш дискусійних.

Навчання іноземної мови за професійним спрямуванням у 70-90-ті роки минулого століття стало предметом наукового розгляду таких вчених, як I. Берман, Т. Серова, С. Фоломкіна, П. Робінсона, Б. Коффі, 3. Боліто. Дослідження зазначених науковців знайшли відображення в роботах
Л. Клименко, О. Тарнопольського, Н. Філіпової, Н. Ягельської, Н. Брайджера і Дж. Комфорта, В. Оллет, Т. Хатчінсона і А. Вотерса. Також зосередили свою увагу на проблемі викладання профільних дисциплін англійською мовою в Україні є Н. Осіпчук [1], А. Ковальчук [2], О. Тарнопольський [3], Є. Покровський [4], В. Полторак, Л. Юрчук, О. Савченко [5], М. Хуторна [6]. Зазначеною проблемою цікавляться й колеги з Росії, зокрема О. Добриніна [7], О. Соколова [7], І. Свирепчук [8] та I. Слісаренко [9].

Майже всі фахівці, які працюють над темою поєднання лінгвістичних дисциплін з профільними у нефілологічних спеціальностях, стверджують, що такий досвід дає лише позитивні результати. Проте механізм застосування нововведення вимагає ретельної підготовки та врахування особливостей 
кожної спеціальності [10; 11]. Саме в цьому і полягає актуальність пропонованої публікації.

У цьому науковому повідомленні ми пропонуємо вдалий варіант вирішення цього питання на основі досвіду викладання фахових дисциплін англійською мовою на кафедрі реклами і зв'язків 3 громадськістю Інституту журналістики Київського університету імені Бориса Грінченка.

Метою публікації є аналіз досвіду викладання фахових дисциплін англійською мовою на кафедрі реклами і зв'язків з громадськістю Інституту журналістики Київського університету імені Бориса Грінченка та оцінка його ефективності.

Враховуючи мету, потрібно виконати такі завдання: представити процес викладання фахових дисциплін англійською мовою на кафедрі реклами і зв'язків з громадськістю Інституту журналістики Київського університету імені Бориса Грінченка, проаналізувати таку практику, з’ясувати потребу в інтеграції лінгвістичних та профільних дисциплін для навчання студентів.

Методи дослідження. Основним методом, що використовувався для створення наукової статті, став описовий, оскільки йдеться про результати практичного досвіду. Для збору інформації, вивчення джерел використано первинні методи. Також застосовано загальні методи наукового пізнання, зокрема порівняння та аналіз (належать до методів теоретичного та емпіричного дослідження) 3 метою аналізу досвіду різних навчальних закладів у сфері викладання фахових дисциплін англійською мовою. На теоретичному рівні дослідження також використано методи переходу від абстрактного до конкретного.

Результати й обговорення. Пропозиція викладати студентам кафедри реклами і зв'язків громадськістю фахові дисципліни англійською мовою виникла не випадково: основні поняття відповідної спеціальності зародилися саме у Сполучених Штатах Америки. Зазначена країна й донині продовжуе тримати лідерство у цій царині. Для того, щоб не відставати від сучасних тенденцій світової рекламної та піар діяльності та мати змогу використовувати першоджерельний досвід, майбутнім фахівцям вкрай необхідно тримати руку на пульсі подій у своєму професійному середовищі. На жаль, рівень володіння іноземною мовою колишніх випускників вищих навчальних закладів в Україні залишається вкрай низьким Як підтверджує В. Александров, «за результатами опитування Міжнародної благодійної організації з удосконалення освіти в Україні (2004р.) 70 \% роботодавців вважають, що випускники технічних ВНЗ не вміють застосовувати іноземну мову для професійного спілкування, і лише 30 \% роботодав- ців констатують достатній рівень володіння іноземною мовою своїх молодих працівників» [12, с. 23].

Кафедра реклами і зв'язків 3 громадськістю Інституту журналістики Київського університету імені Бориса Грінченка пропонує викладання англійською мовою таких профільних дисциплін: «Копірайтинг у рекламі», «Копірайтинг у $\mathrm{PR}$, «Соціальна реклама», «Теорія масової інформації», «Комунікаційні стратегії». Це дасть змогу використовувати у навчальному процесі оригінальні джерела. Ідеться про друковані неперекладені видання провідних фахівців сфери реклами та зв'язків 3 громадськістю, масової комунікації: «Effective public relations» (Scott M. Cutlip, Allen H. Center, Glen M. Broom), «Advertising» (Frank Jefkins), «Writing for the mass media» (James Glen Stovall), «Media writer's handbook» (George T. Arnold), «The media of mass communication» (John Vivian), «The dynamics of mass communication. Media in the digital age» (Joseph R. Dominick), «Mass media. Mass culture» (James R Wilson, S. Roy Wilson), «Communication theories» (Werner J. Severin, James W. Tankard), «Communication research: issues and methods» (James A. Anderson), «Political campaign communication: inside and out» (Larry Powell, Joseph Cowart) та ін. Також з'являеться можливість використовувати електронні ресурси провідних рекламних агентств світу (BBDO тощо), що відповідає вимогам сучасного часу.

Національні рекламні структури зазвичай активно співпрацюють 3 іноземними компаніями. Тому вимогою сучасних роботодавців у сфері реклами та зв'язків з громадськістю до фахівців зазначеної сфери нині є саме знання як мінімум англійської мови, а то й інших мов саме в контексті рекламної та PR галузей. «Розширення міжнародних зв'язків, входження України в Свропейський простір, можливість закордонного працевлаштування вимагає високої професійної іншомовної компетенції випускників технічних ВНЗ України» [4]. Ідеться не лише про всебічний розвиток студента як людини та подолання мовний бар'єра, а й про відповідність майбутніх фахівців компетенціям після закінчення вишу та якісну підготовку студента як професіонала, що є завданням будь-якого навчального закладу як освітньої структури.

«У практиці ж навчання іноземної мови у негуманітарних ВНЗ часто спостерігається розрив між змістом професійного навчання та основними характеристиками навчання іноземної мови <..> Практичне вміння випускників немовних вузів, на жаль, обмежується читанням і перекладом текстів зі спеціальності і виконанням деяких лексичних і граматичних вправ на основі текстів. Мало хто із 
студентів вміє ефективно спілкуватися іноземною мовою навіть в межах побутової тематики» [1].

Кафедра реклами і зв’язків 3 громадськістю Інституту журналістики Київського університету імені Бориса Грінченка вже другий рік здійснює викладання англійською мовою профільних дисциплін «Копірайтинг у рекламі», «Копірайтинг в $\mathrm{PR}$, «Соціальна реклама», «Теорія масової інформації», «Комунікаційні стратегії». Ініціатори нововведення офіційно називають свою пропозицію освітнім експериментом. Проте фактично експериментом така ініціатива була лише у 2015 році. Зараз навчання за такою моделлю студенти сприймають як належне.

Як свідчить досвід, студентів, охочих вивчати фахові дисципліни англійською мовою, вже на першому курсі близько 40 \%. Крім того, нерідко саме почувши під час вступної кампанії про таку освітню послугу від кафедри, абітурієнт приймає остаточне рішення про вступ до того чи того навчального закладу. Отже, викладання профільних дисциплін англійською мовою - не безперспективна ілюзія представників освітньої галузі, а вимога сучасності.

Охарактеризуємо процес вивчення профільних дисциплін англійською мовою на кафедрі реклами і зв'язків з громадськістю Інституту журналістики Київського університету імені Бориса Грінченка.

На початку кожного семестру викладач кафедри, який має кваліфікаційний рівень володіння англійською мовою та відповідний практичний досвід викладання дисциплін «Копірайтинг у рекламі», «Копірайтинг у PR», «Соціальна реклама», «Теорія масової інформації», «Комунікаційні стратегії», пропонує потокові студентів, а це перший та четвертий курси, альтернативу традиційному засвоєнню навчального матеріалу. Студенти, що бажають долучитися до інноваційного навчання, офіційно підтверджують свою згоду.

Проведення занять із зазначених дисциплін англійською мовою передбачає виконання ситуаційних та творчих завдань, участь у рольових іграх, підготовку презентацій, написання дайджестів, індивідуальних проектів, складання словника з базових термінів дисципліни, аналіз друкованих, аудіо- та відеоматеріалів, ведення опорного конспекту лекцій, підготовку до експрес-контролю та модульного контролю. Зокрема, самостійна робота студентів здійснюється під час підготовки до поточних аудиторних занять: вивчення лекційного матеріалу, обов'язкової й додаткової англомовної літератури 3 профілю; підготовки до модульного контролю та інших форм поточного контролю; ведення опорного конспекту лекцій. Аналітичну роботу студенти проводять, здійснюючи огляд англомовних джерел із запропонованої проблематики, пишучи дайджести 3 певної теми, аналізуючи друковані, аудіо- та відеоматеріали; готуючи тематичні презентації та індивідуальні проекти, складаючи словник базових термінів дисципліни.

Фактично вивчення профільних дисциплін безперешкодно поєднується 3 методикою класичного навчання. Щоб запровадити таке нововведення, потрібна лише організаційна ініціатива навчального закладу.

У результаті опанування дисциплін англійською мовою студент здобуває інформаційну, комунікативну, управлінську, дослідницько-прогностичну, проектно-творчу, технологічну фахові компетентності. Також перевагою такого навчання $є$ те, що воно дає змогу готувати кадри для навчального закладу (якщо випускник у перспективі вирішить продовжити кар'єру в освітній галузі). Це вирішило б проблему інтеграції лінгвістичних та фахових знань викладача, про яку згадують дослідники у своїх працях, розглядаючи питання викладацької компетенції. 3окрема йдеться про те, що «бурхливий розвиток міжнародних відносин вимагає дедалі більшої кількості викладачів іноземної мови для навчання студентів нефілологічних спеціальностей, виникає проблема адаптації випускників мовних вищих навчальних закладів до викладання іноземної мови для спеціальних цілей» [13].

Як свідчить практика роботи в інших навчальних закладах, часто на перешкоді належній організації викладання профільних дисциплін стає відсутність фахівців. Та іноді така незабезпеченість відповідними кадрами пов'язана не 3 фактичною їх відсутністю, а 3 небажанням освітніх установ виділяти кошти для матеріального заохочення навчально-педагогічних працівників, що мають відповідну кваліфікацію. На такий недолік вказують й інші науковці, які мали досвід відмови у вирішенні фінансового питання. «Молоді викладачі спецдисциплін, що активно взялись спочатку за ведення АМ-занять, повернулись до традиційних форм, не в останню чергу мотивуючи цей крок відсутністю хоча б мінімального фінансового стимулу. На жаль, згадана єдина спецдисципліна тримається і сьогодні єдино на ентузіазмі викладача замість того, щоб служити предметом наслідування для молодих колег-предметників» [4]. Саме тому рівень мотивації викладачів, які мають можливість забезпечувати викладання фахових дисциплін англійською мовою, є вкрай низьким. Цей напрям тримається лише на ентузіазмі та ініціативі окремих навчально-педагогічних працівників.

«Постановка завдання навчання іншомовного спілкування в умовах нелінгвістичного вузу часто

Іатегровані комунікації, 2016 
викликає скептичне ставлення у зв'язку з дуже обмеженою кількістю навчальних годин» [1], що також перешкоджає розвитку зазначеного методу навчання.

Вирішити зазначені проблеми, тим самим сприяючи розвитку галузі викладання профільних дисциплін англійською мовою, можна лише в одному випадку: до такого нововведення потрібно залучати не окремих навчально-педагогічних працівників, a навчальний заклад загалом. Зокрема, проблему обмеженості кількості навчальних годин можна вирішити шляхом інтеграції лінгвістичних дисциплін з профільними. Пропонуємо також фінансово мотивувати викладацький склад, який в змозі здійснювати викладання англійською мовою для студентів нелінгвістичної спеціальності. Такі витрати швидко були б відшкодовані, адже колектив викладачів поповнився б новими кадрами із лав студентів. Також необхідним напрямом роботи вважаємо налагодження співпраці навчальних закладів із закодорннми ВНЗ щодо питання залучення іноземних колег до наповнення національних бібліотек вишів англомовними неперекладними джерелами 3 профільних дисциплін. Адже, наприклад, «бібліотека» англомовних друкованих джерел для студентів на кафедрі реклами і зв’язків з громадськістю Інституту журналістики Київського університету імені Бориса Грінченка стала результатом клопіткої праці саме їі представників. Також для розвитку напряму викладання фахових дисциплін англійською мовою пропонуємо інтегрувати роботу викладачів філологічних спеціальностей та викладачів нелінгвістичного напряму.

Висновки. Вважаємо, що напрям викладання профільних дисциплін англійською мовою має перспективи, оскільки їх вивчення поєднується з методикою класичного навчання. Тому запровадження такого нововведення у навчальний процес вважаємо доцільним у кожному вищому навчальному закладі України.

\section{Список літератури}

1. Осіпчук Н. В. Проблематика навчання іноземної мови у технічних вищих навчальних закладах / Н. В. Осіпчук // Наукові записки Тернопільського національного педагогічного університету імені Володимира Гнатюка. Сер. : Педагогіка. - 2011. - № 4. C. 204-213.

2. Ковальчук А. О. Із досвіду викладання білінгвальних дисциплін майбутнім магістрам у провінційному ВНЗ / А. О. Ковальчук // Вісник ХНУ. Викладання мов у вищих навчальних закладах освіти на сучасному етапі. Міжпредметні зв'язки. Наукові дослідження. Досвід. Пошуки. - 2010. - Вип. 16 . - С. 108-114.

3. Тарнопольський О. Б. Навчання через зміст спеціальності в курсах іноземної мови для спеціальних цілей у немовних вишах / О. Б. Тарнопольський / / Вісник ЛНУ ім. Т. Шевченка. - 2011. - № 12 (223). - Ч. II. - С. 147-156.

4. Покровський Є. О. Досвід викладання спеціальних дисциплін англійською мовою у технічному університеті. Нотатки з кадрового забезпечення / С.О. Покровський, В. П. Полторак, Л. Ю. Юрчук // Вісник НТУУ «КПІ». Сер. : Філософія. Психологія. Педагогіка. - 2014. - Вип. 1. - С. 116-122.

5. Савченко О. О. Розвиток іншомовної комунікативної компетентності студентів інженерно-технічного профілю / О. О. Савченко / / Вісник ХНУ. Викладання мов у вищих навчальних закладах освіти на сучасному етапі. Міжпредметні зв'язки. Наукові дослідження. Досвід. Пошуки. - 2010. - № 16. - С. 187-194.

6. Хуторна М. Е. Системний підхід до формування іншомовної професійної комунікативної компетенції при підготовці фахівців із банківської справи / М. Е. Хуторна, О. М. Бартош // Вісник Університету банківської справи НБУ. - 2013. - № 3. - С. 305-308.

7. Добринина О. Л. Концепция непрерывного иноязычного образования в неязыковом вузе / О. Л. Добринина, Е. И. Соколова // Психология и педагогика: методика и проблемы практического применения. - Новосибирск : Изд-во НГТУ, 2011. - С. 386-390.

8. Свирепчук И. А. Особенности обучения иностранным языкам студентов технических вузов / И. А. Свирепчук // Вісник НТУУ «КПІ». Сер. : Філософія. Психологія. Педагогіка. - 2012. - № 1 (34). C. $136-138$.

9. Слесаренко И. В. Подготовка по иностранным языкам в техническом университете: от студента до преподавателя / И. В. Слесаренко // Высшее образование в России. - 2011. - № 4. - С. 90-94.

10. Загальноєвропейські рекомендації з мовної освіти: вивчення, викладання, оцінювання. - Київ : Ленвіт, 2003. -273 c.

11. Офіційний сайт глобальної Академії Cisco [Електронний ресурс]. - Режим доступу: http://www.cisco. com/web/learning/netacad/index.html.

12. Александров В. М. Методика інтенсивного навчання інженерів професійно-орієнтованої англійської мови : автореф. дис. ... канд. пед. наук : 13.00.02 / В. М. Александров. - Одеса, 2009.

13. Міжпредметна координація у навчанні професійно спрямованої англійської мови та фахових дисциплін [Електронний ресурс]. - Режим доступу: http://

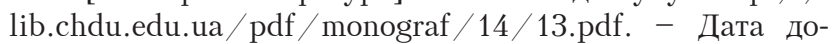
ступу: 30. 09. 2015.

\section{Reference list}

1. Osipchuk N. V. Problematyka navchannia inozemnoi movy u tekhnichnykh vyshchykh navchalnykh zakladakh / N. V. Osipchuk // Naukovi zapysky Ternopilskoho natsionalnoho pedahohichnoho universytetu imeni Volodymyra Hnatiuka. Ser. : Pedahohika. - 2011. № 4. - S. 204-213.

2. Kovalchuk A. O. Iz dosvidu vykladannia bilinhvalnykh dystsyplin maibutnim mahistram $\mathrm{u}$ provintsiinomu VNZ / A. O. Kovalchuk // Visnyk KhNU. Vykladannia mov u vyshchykh navchalnykh zakladakh osvity na suchasnomu etapi. Mizhpredmetni zviazky. Naukovi 
doslidzhennia. Dosvid. Poshuky. - 2010. - Vyp. 16 . S. $108-114$.

3. Tarnopolskyi O. B. Navchannia cherez zmist spetsialnosti v kursakh inozemnoi movy dlia spetsialnykh tsilei u nemovnykh vyshakh / O. B. Tarnopolskyi // Visnyk LNU im. T. Shevchenka. - 2011. - № 12 (223). Ch. II. - S. $147-156$.

4. Pokrovskyi Ie. O. Dosvid vykladannia spetsialnykh dystsyplin anhliiskoiu movoiu u tekhnichnomu universyteti. Notatky z kadrovoho zabezpechennia / Ie. O. Pokrovskyi, V. P. Poltorak, L. Iu. Yurchuk // Visnyk NTUU «KPI». Ser. : Filosofiia. Psykholohiia. Pedahohika. - 2014. Vyp. 1. - S. 116-122.

5. Savchenko O. O. Rozvytok inshomovnoi komunikatyvnoi kompetentnosti studentiv inzhenernotekhnichnoho profiliu / O. O. Savchenko / / Visnyk KhNU. Vykladannia mov u vyshchykh navchalnykh zakladakh osvity na suchasnomu etapi. Mizhpredmetni zv'iazky. Naukovi doslidzhennia. Dosvid. Poshuky. - 2010. № 16. - S. 187-194.

6. Khutorna M. E. Systemnyi pidkhid do formuvannia inshomovnoi profesiinoi komunikatyvnoi kompetentsii pry pidhotovtsi fakhivtsiv iz bankivskoi spravy / M. E. Khutorna, O. M. Bartosh // Visnyk Universytetu bankivskoi spravy NBU. - 2013. - № 3. S. $305-308$

7. Dobrinina O. L. Koncepcija nepreryvnogo inojazychnogo obrazovanija $\mathrm{v}$ nejazykovom vuze /
O. L. Dobrinina, E. I. Sokolova // Psihologija i pedagogika: metodika i problemy prakticheskogo primenenija. - Novosibirsk : Izd-vo NGTU, 2011. S. $386-390$.

8. Svirepchuk I. A. Osobennosti obuchenija inostrannym jazykam studentov tehnicheskih vuzov / I. A. Svirepchuk // Visnik NTUU «KPI». Ser. : Filosofija. Psihologija. Pedagogika. 2012. - № 1 (34). - S. 136-138.

9. Slesarenko I. V. Podgotovka po inostrannym jazykam $\mathrm{v}$ tehnicheskom universitete: ot studenta do prepodavatelja / I. V. Slesarenko / / Vysshee obrazovanie v Rossii. - 2011. - № 4. - S. 90-94.

10. Zahalnoi evropeiski rekomendatsii $\mathrm{z}$ movnoi osvity: vyvchennia, vykladannia, otsiniuvannia. - K. : Lenvit, 2003. - 273 c.

11. Ofitsinyi sait hlobalnoi Akademii Cisco [Electronic resource]. - Reference: http://www.cisco. com/web/learning/netacad/index.html.

12. Aleksandrov V. M. Metodyka intensyvnoho navchannia inzheneriv profesiino-oriientovanoi anhliiskoi movy : avtoref. dys. ... kand. ped. nauk : 13.00.02 V. M. Aleksandrov. - Odesa, 2009.

13. Mizhpredmetna koordynatsiia u navchanni profesiino spriamovanoi anhliiskoi movy ta fakhovykh dystsyplin [Electronic resource]. - Reference: http://lib. chdu.edu.ua/pdf/monograf/14/13.pdf. - Accessed: 30. 09. 2015.

Подано до редакиї 15. 09. 2015 р.

Вернигора С. Н., канд. наук из соц. коммуник., доцент, Институт журналистики Киевского университета имени Бориса Гринченко

\title{
ПРЕПОДАВАНИЕ ДИСЦИПЛИН ПО СПЕЦИАЛЬНОСТИ НА АНГЛИЙСКОМ ЯЗЫКЕ В УКРАИНСКОМ ВЫСШЕМ УЧЕБНОМ ЗАВЕДЕНИИ:$$
\text { ОБРАЗОВАТЕЛЬНЫЙ ЭКСПЕРИМЕНТ ИЛИ ПОТРЕБНОСТЬ СЕГОДНЯШНЕГО ДНЯ }
$$ ( НА ПРИМЕРЕ ДИСЦИПЛИН КАФЕДРЫ РЕКЛАМЫ И СВЯЗЕЙ С ОБЩЕСТВЕННОСТЬЮ ГУМАНИТАРНОГО ИНСТИТУТА КИЕВСКОГО УНИВЕРСИТЕТА ИМЕНИ БОРИСА ГРИНЧЕНКО)
}

\begin{abstract}
Аннотация. Публикация посвящена опыту преподавания на английском языке дисциплин по специальности «Копирайтинг в рекламе», «Копирайтинг в $P R »$, «Соцальная реклама», «Теория массовой информации», «Коммуникационные стратегии» на кафедре рекламы и связей с общественностью Гуманитарного института Киевского университета имени Бориса Гринченко. Приведены цель, результаты и перспективы развития такого направления обучения студентов .
\end{abstract}

Ключевые слова: высшее образование, реклама и связи с общественностью, преподавание дисциплин на английском языке. 